Review Article

\title{
Health education and community mobilization in Nigeria; issues and prospects
}

\author{
Ogbonna Brian O*, Ezenekwe Lizette N, Isidienu Chika P
}

\begin{abstract}
Department of Clinical Pharmacy and Pharmacy Management, Faculty of Pharmaceutical Sciences, Nnamdi Azikiwe University Awka, Nigeria
\end{abstract}

Received: 31 March 2016

Accepted: 07 May 2016

\section{*Correspondence:}

Dr. Ogbonna Brian O,

E-mail: bo.ogbonna@unizik.edu.ng

Copyright: (c) the author(s), publisher and licensee Medip Academy. This is an open-access article distributed under the terms of the Creative Commons Attribution Non-Commercial License, which permits unrestricted non-commercial use, distribution, and reproduction in any medium, provided the original work is properly cited.

\begin{abstract}
The importance of health to national development and poverty reduction over the centuries, in that improving health status and increasing life expectancy contribute to long-term economic development. This article examined the state of health education and community mobilization in Nigeria's health care delivery. The electronic search of relevant materials was carried out and those that met the inclusion criteria were used for the study. Health literacy is vital to power and support government efforts in promoting health for all. Study suggested that $80 \%$ of Africans use traditional medicines while $85 \%$ of Nigerians consult traditional medicine healers. Many developing countries, especially those in Sub-Saharan Africa, in the 1970s experienced remarkable and unacceptable inequalities in the provision and distribution of health services. This contributed to and explained the exploration of different approaches to improve health care delivery by international health organizations in the 1970s.
\end{abstract}

Keywords: Community, Education, Health, Grass root, Mobilization, Nigeria

\section{INTRODUCTION}

China had made the most remarkable contribution to improving health care for all by promoting a communitybased framework for health care delivery to its population. This bottom-up approach, which focused on prevention and management of health problems in their social setting, turned out to be a better option to the typical top-down, technological approach and rekindled hope about the possibility of addressing inequality to improve universal health. It was against this background that in 1978, 'health for all' was introduced and endorsed at an international conference on primary health care (PHC) in Alma Ata, Kazakhstan. Primary health care (PHC) is driven by a political philosophy that emphasizes a radical change in both the design and content of conventional health care services. It also advocates an approach to health care principles that allow people to receive health care that enables them to lead socially and economically productive lives. The Alma-Ata declaration of September 1978 defined the concept of PHC as, essential care based on practical, scientifically sound and socially acceptable health care methods and technology, made universally accessible to individuals and families in the community through their full participation, and at a cost that the community and country can afford to maintain at every stage of their development in the spirit of self-reliance and self-determination. It forms an integral part both of any country's health system, of which it is the central function and focus, and of the overall social and economic development of the community. It is the first level of contact for individuals, the family and the community within the national health system, bringing health care as close as possible to where people live and work, and constitutes health care services. ${ }^{1}$ This article examined the state of health 
education and community mobilization in Nigeria's health care delivery.

\section{Community mobilization and participation}

Community mobilization and participation plays a key role in utilization of health services, by ensuring ownership and sustainability of health programs and interventions. It involves encouraging the community to take part in their health care and development. It is a lengthy process and not only implies that the community members, government and NGOs come together to develop a strategy to resolve issues within the community, but also entails the pooling of their resources. A key component of community mobilization involves identifying and developing leaders from the community by strengthening and building their capacities in various issues. Community mobilization is neither a campaign that is undertaken once, nor is it a series of campaigns carried out over a period. A continual and cumulative communication through educational and organizational processes produces a growing autonomy and consciousness in the community about taking development into their hands. Such efforts need to be sustainable and sustainability of social change is more likely if the individuals and communities have a sense of ownership in the development process and that communities should be the agents of their own change. The communities should be mobilized to participate in their development or health activities from the planning to implementation, monitoring and evaluation phases to ensure ownership and sustainability. The establishment of health development committees is one way of ensuring community participation and could be used to mobilize the community. ${ }^{2,3}$

\section{Health education and primary health care in retrospect}

Comprehensive health centers are primary health care facilities providing promotive, preventive, curative and rehabilitative services to a community. They may be well built and equipped with adequate resources human, material; and well-funded with taxpayer's money, but grossly underutilized due to several factors that may be economic, educational, geographical, socio-cultural, political, and legal or religious. ${ }^{4,5}$ In Africa, up to $80 \%$ of the population uses traditional medicine for primary health care. Eighty-five per cent of Nigerians use and consult traditional medicine for healthcare, social and psychological benefits. ${ }^{6-8}$ In rural Burkina Faso, modern health care facilities are only consulted by $19 \%$ of the population; others choose home treatment 52\%, traditional healers $17 \%$, or local village health workers $5 \%$. This translates in a utilization of government services as low as 0.17 consultations per capita in $1997 .{ }^{9}$ In Ghana, Mali, Nigeria and Zambia, herbal medicines are the first line of treatment for 60 per cent of children with high fever from malaria. ${ }^{10}$ About $60-85$ per cent of births delivered in Nigeria and especially in the rural communities are by the traditional birth attendants and these take place outside the health facilities. Many patients prefer to seek care at the patent medicine stores or with the traditional medicine operators instead of the formal health sector. ${ }^{7,11,12}$

\section{Health promotion and disease prevention}

At a critical time when emphasis is on prevention of diseases, it is expected that school authorities, teachers, students, governments and the community will adequately support health instruction in the schools. ${ }^{13} \mathrm{~A}$ well-structured pattern of health instruction in schools is an impetus to effective living, health promotion and disease prevention. The problems associated with the absence of health instruction in schools poses a threat and without their timely resolutions, schools would be unable to provide students with the greatest possible assess to variety of learning let alone equip them intellectually, socially and emotionally. ${ }^{14,15}$ In spite of the seemingly interest of school authorities in health education, they do not provide an ideal teaching and learning environments, moreover, the schools do not have a developed teaching guide outlining progressive plan for health instruction. ${ }^{16}$ The aforementioned features show that health education in schools contends with administrative related problems in schools. This finding is in support of Ejifugha's view that health education in Nigerian schools lack definition due to administrative constraints. This finding also contradicts Frank claim that administrative factors have little or no influence over health instruction. ${ }^{17,18}$ There is evidence from extant literature that health education curriculum is most apt to function if school administrators provide the necessary materials for teaching. For schools to do otherwise is to help to incorrectly implement the health education curriculum. ${ }^{19,20}$ Another disturbing finding arising from this study is the period of teaching health per week. The absence of an ideal teaching period for health instruction in the schools will certainly compound the process of health education curriculum implementation. ${ }^{21}$ The nigerian association of health education teachers (NAHET) has suggested a minimum period of time for health instruction in schools to be every day and that the reality of this depend on the willingness of school authorities, teachers, students and the community to participate in health instructional activities. ${ }^{22-24}$ The Association posited that health is an everyday affair so that repetitive study will enhance health promotion in all circumstances. $^{23}$

\section{Prospects of health education in Nigeria}

Notwithstanding many problems hindering community education in Nigeria, it has many prospects, as one of the factors underpinning growth and development. In the first place, community education remains a mechanism through which mass involvement in learning activities can progress. In this wise, community education has the potentiality of improving the ability to think, especially important in a fast-moving current of change and 
knowledge boom. This corroborates the view of Anyanwu that there is a need for an emphasis on community education, which he describes as science of all the sciences of interrelationships of knowledge, a critical area beyond compartmentalization, where knowledge must be integrated in order to have proper meaning. ${ }^{25,26}$ This suggests that while there is need for specialization, it is important to avail one of the knowledge in other disciplines. ${ }^{27}$ Community education remains an important tool in enhancing citizen involvement, the sharing of decision-making and total community participation in the education enterprise. ${ }^{28,29}$ Awareness is better created through community education among women, youths, trade unions, local or grass root institutions and organizations that government cannot on its own solve all the problems of educational development in Nigeria. ${ }^{28}$ Such participation can be in the areas of policy formulation, determining areas of priority in education, mobilizing resources and the provision of facilities. Thus, non-formal community education deserves very special attention in view of its immense potentials in making community members responsive to educational transformation. $^{28}$

The quest for moral and ethical re-orientation is needful and actual sable in Nigeria through community education. Undoubtedly, obnoxious and ignoble activities pervade the Nigerian educational institutions, thereby eroding them of their expected noble ideals and goals. Such activities include examination malpractices, drug abuse, killing, sexual harassment, raping and maiming. Community education can be a panacea for achieving the eight Millennium Development Goals (MDGs) in Nigeria. $^{30}$

\section{CONCLUSION}

The MDGs advocate poverty reduction, education for national health, gender equality and aim at combating child mortality, HIV/AIDs and other diseases. Going by the present rate of progress, President of the Nigerian National Council for Adult Education (NNCAE) expressed his dismay that a number of countries including Nigeria may not be able to achieve the MDGs by the target date of 2015 . He attributes this untoward situation among many other things to the insufficient public awareness and a failure to mobilize communitylevel understanding and support through the civil society organizations and media. The implication is that the MDGs have to be a community program to be achieved. Community education in this vein has a great potential in developing the process by which the community members can learn and work together within the purview of MDGs to identify their needs or community problems and with governmental and non-governmental agencies' inputs they will thus seek solutions to their identified problems.

Funding: No funding sources Conflict of interest: None declared

\section{Ethical approval: Not required}

\section{REFERENCES}

1. Alma Ata. Primary Health Care: Report of the International Conference on Primary Health Care, Jointly sponsored by the World Health Organization (WHO) and the United Nations Children's Fund (UNICEF), 1978.

2. Adah SO, Ogbonna C, Anga $\mathrm{P}$, Chingle MP, Ashikeni MA, Envuladu E, et al. The impact of advocacy and community mobilization on the utilization of health services at the comprehensive health centre, gindiri. Available at (http://www.ajol.info/index.php/jjm/article/downloa d/55093/43 567). Accessed on 12 February 2016.

3. Adeyinka AA. Widening access to education in the era of globalization: future policy trusts. In Akpovire, Oduaran, Bhola, eds. Widening access to education as social justice. Springer. The Netherlands. 2006;441-63.

4. Okonkwo JEN, Ngene JN. Determinants of poor utilization of orthodox health facilities in a nigerian rural community. Niger J Clin Pract. 2004:7(2);748.

5. Fosu GB. Childhood morbidity and health services utilization: cross-national comparisons of userrelated factors from DHS data. Soc Science Med. 1994;38(9);1209-20.

6. Williamsn K. Do $80 \%$ of S. Africans regularly consult traditional healers? The claim is false https://africacheck.org/reports/do-80-of-southafricans-regularly-consult-traditional-healers-theclaim-is-false/\#sthash.DgNrHhVI.dpuf or www.africacheck.

7. Science and Development Network. Traditional Medicine. www.google.com

8. Traditional Medical Care in Nigeria. Available at Online Nigeria_com.htm. Accessed on May 14, 2008.

9. Baltussen R, Yazoume Y. Quality of care of modern health services as perceived by users and non-users in Burkina Faso. Int $\mathbf{J}$ Qual Health Care. 2005:18(1);30-4.

10. Buor D. Analyzing the primacy of distance in the utilization of health services in the ahafo-ano south district of ghana. Int $\mathbf{J}$ Health Plann Manage. 2003:18(4);293-311.

11. Diop FP. Economic determinants of child health and the utilization of health services in Sub-Saharan Africa the case of Ivory Coast. Ann Arbor, Michigan, University Microfilms International, 1990;213.

12. Obionu $\mathrm{CN}$. Primary health care for developing countries. Ezu Books 1td. $2^{\text {nd }}$ ed. 2007:1-24.

13. Barikor $\mathrm{CN}$. Contemporary issues in community development education. Adult Education in Nigeria. Canadian Association for Community Education. 1984;9:92-100. 
14. Delargy PF. Public schools and community education. In: S. B. Merriam and P. M. Cunningham eds. Handbook of Adult and Continuing Education, San Francisco: Jossey-Bass, 1989.

15. Dublin Declaration, Quoted in C. N. Anyanwu (2002). Community Education: The African dimension, Ibadan. Department of Adult Education, University of Ibadan. 1983.

16. Gold BS. Health education teacher resource handbook; a practical guide for $\mathrm{k} 12$ health education. Newton, MA: Educational development centre, 1994;1-40.

17. Ejifugha AU. Development of health education in nigeria. Owerri: Canon Publisher Nigeria Ltd;1999.

18. Frank HJ. Peer education: the unauthorized version. B Edu Res J. 1988;24(2):179-93.

19. Idehen CO. Implementation of the national health education curriculum in secondary schools in edo state. Thesis submitted to the University of Benin, Benin City, Nigeria, 2004.

20. Ezimah MOA. Knowing adult education: Its nature, scope and processes; Owerri: Springfield Publishers Ltd.

21. Eke AN. Status of health education in Anambra secondary schools. In E.T, Izaugie, M.A. Olaitan, S.O. eds. Implementation of National Policy on Education: Theoretical and Empirical Analysis. Ehiamatalor. Benin City: NERA Publications, University of Benin, 1989:262-297.

22. Dawson N. What primary school teachers think of drugs education in their school. Health Educ J. 1997;56:364-75.
23. Oberteuffer DO. Harrelson, Pollock M. School Health Education. $5^{\text {th }}$ Ed. New York: Harper and Row Publishers; 1985.

24. Owie I. Semantic analysis of primary school teachers perception of health education as a school subject. Nigerian Educational Forum. 1992;13-1.

25. Bernard B. How schools convey high expectations for kids. Western Centre News. 1992;5(3):11-5.

26. Anyanwu CN. Community education: The african dimension. Department of adult education, University of Ibadan, Ibadan. 2002.

27. Bowling A. Research methods in health: Investigating Health Services. Buckingham: University Press, 1999.

28. Ademuwagun ZA. Education laws related to health in nigeria. Ibadan: Department of Preventive and Social Medicine. University of Ibadan. 1977.

29. Adetokunbo O. Lucas and Herbert M. Gilles. Short textbook of public health medicine for the tropics. Book power. $4^{\text {th }}$ ed. 2003:4:283-7.

30. Fasokun TO. Non-formal education as a nigerian strategy for the actualization of the united nations millennium development goals. An Opening Address delivered at the Nigerian National Council for Adult Education (NNCAE) conference held in Calabar. 2006;20-22.

Cite this article as: Brian OO, Lizette NE, Chika PI. Health education and community mobilization in Nigeria; issues and prospects. Int J Community Med Public Health 2016;3:1348-51. 